\title{
Management of Coconut Mite in Bangladesh Involving Communities as Implanter
}

\author{
${ }^{1}$ Md. Nazirul Islam; ${ }^{2}$ Ishaqul Islam; ${ }^{3}$ Mst. Shamsunnahar
}

\begin{abstract}
A study on management of coconut mite (Aceria guerreronis Keifer, Acari: Eriophyidae) was carried out in farmers fields at Bagharpara Sub-district of Jashore district, in an area of about 696 ha during May 2011 to June 2014. The mite attacking coconut in Bangladesh remained unidentified until 2008. Field and laboratory studies on morpho-anatomy revealed that 2-6 month old nuts hosted colonies of mites while no mites were found on unfertilized button (flowers) and nuts of more than 06 months old. Colonization was found maximum in younger nuts of $3-4$ month old. Mites were found to reside under the perianth near the stalk of young coconut. Six different treatments viz, removing of infested young nuts and foliar application of Omite@ $0.2 \%$ adjacent to the bunch region $\left(T_{1}\right)$; removing of infected young nuts and foliar application of Neem-oil @ 0.3\% adjacent to the bunch region $\left(T_{2}\right) ; T_{1} \&$ soil incorporation of Neem cake @ $500 \mathrm{~g} /$ tree $\left(T_{3}\right) ; \mathrm{T}_{1} \&$ soil incorporation of trichocompost@2000g/tree $\left(T_{4}\right) ; \mathrm{T}_{2} \&$ soil incorporation of Neem cake @ 500g/tree $\left(T_{5}\right)$ and $T_{2} \&$ incorporation of tricho-compost $2000 \mathrm{~g} /$ tree $\left(T_{6}\right)$. Results of three consecutive years showed that all the treatments were equally effective in controlling mite attack in coconut. Edible portion of mature nuts was found to improve by the treatments $T_{3}$ and $T_{5}$, containing soil incorporated Neem cake. Days to spath opening, male phase, number of bunch and nut per bunch were not influenced by any one of the treatments. On an average 77 nuts were harvested/palm/year and their estimated market value was Taka 1540. Income augmented due to technology was Taka 1339.80 with BCR value 6 .
\end{abstract}

Key words: Aceria guerreronis, Bangladesh, Coconut Mite, Neem Cake, Tricho-compost, Omite, Eriophyid.

\section{Introduction}

Coconut is considered a subsistence crop in Bangladesh and gives income round the year. It is mainly cultivated in the homesteads with other fruits and vegetables. However, orchard plantation is not uncommon in the off-shore islands and in the seashore in the southern part of the country. In Bangladesh coconut is afflicted frequently with natural calamities and outbreak of anonymous pests and diseases. Coconut mite (Aceria guerreronis Keifer) infestation is such a problem in coconut in Bangladesh, which remained unidentified until 2008. It has taken an epidemic turn in south and southwestern regions. A. guerreronis (Acari: Eryophyidae) resides under the bracts (perianth) causing damage to young fruits of coconut (Brian et al., 1999; Fernando et al., 2002) resulting in small

\footnotetext{
${ }^{1}$ Chief Scientific Officer, Plant Genetic Resource Centre (PGRC), Bangladesh Agricultural Research Institute (BARI), Gazipur, Bangladesh.

${ }^{2}$ Senior Scientific Officer (Entomology), Regional Agriculture Research Station, Jassore.

${ }^{3}$ Principal Scientific Officer (Plant Pathology), Horticulture Research Centre (HRC), BARI, Gazipur, Bangladesh.

Corresponding Author: Dr. Md. Nazirul Islam, CSO, PGRC, BARI, Gazipur, 1701, Bangladesh. Email: nazirhrc@yahoo.co.in; pd.pgrc@bari.gov.bd
} 
sized, deformed fruits and immature nut fall. Due to continuous yield losses many farmers have cut down their coconut palms and shifted to farming other fruit and/or field crops. Since, mite was not recognized at early stage of infestation, exact data on yield loss of coconut are not avaialable in the country. According to FAO STAT (2018), production of coconut in Bangladesh was 89 thousand tons in 2001 which was reduced to 80 thousand tons in 2011. It is suspected mite infestation was one the awful causes of such drop in coconut production in Bangladesh. Islam et al. (2008) has found that removal of infested and young nuts up to six months old of mite infested palms and spraying newly developing fruits with "omite" (Abamectin), a sulfite ester group., targeted to prevent further infestation have been proven effective to control coconut mite. They have suggested a large scale investigation in the farmers' fields to confirm the result. Considering the importance of coconut as a potential crop in the county, the present study was undertaken to manage coconut mite through mechanical control by removal of infested fruits followed by application of chemical pesticides and bio-chemicals for prevention of infestation of newly developing nuts.

\section{Materials and Methods}

A three year study was carried in an area of about 696 ha in Bagharpara sub-district under the district of Jashore (Longitude, $89^{0} 06^{\prime}-89^{\circ} 28^{\prime}$ and Latitude, $23^{0} 04^{\prime}-23^{0} 20^{\prime}$ ) comprising six consecutive villages. The location of the study was $12 \mathrm{~km}$ towards East of the Regional Agricultural Research Station (RARS), a southwestern research station of BARI (Figure 1). A pre-prospecting survey was conducted for demarcating the study area and counting the number of palms in the area. A local land-map was used to estimate the area comprising in the study site. Randomized Complete Block Design (RCBD) was adopted and the whole area was divided into three sub-locations as Bloc I, Block II and Block III where treatments were replicated thrice. There were six treatments and each treatment included five (5) palms. Altogether there were $90 \quad(6 \times 5 \times 3)$ palms in the

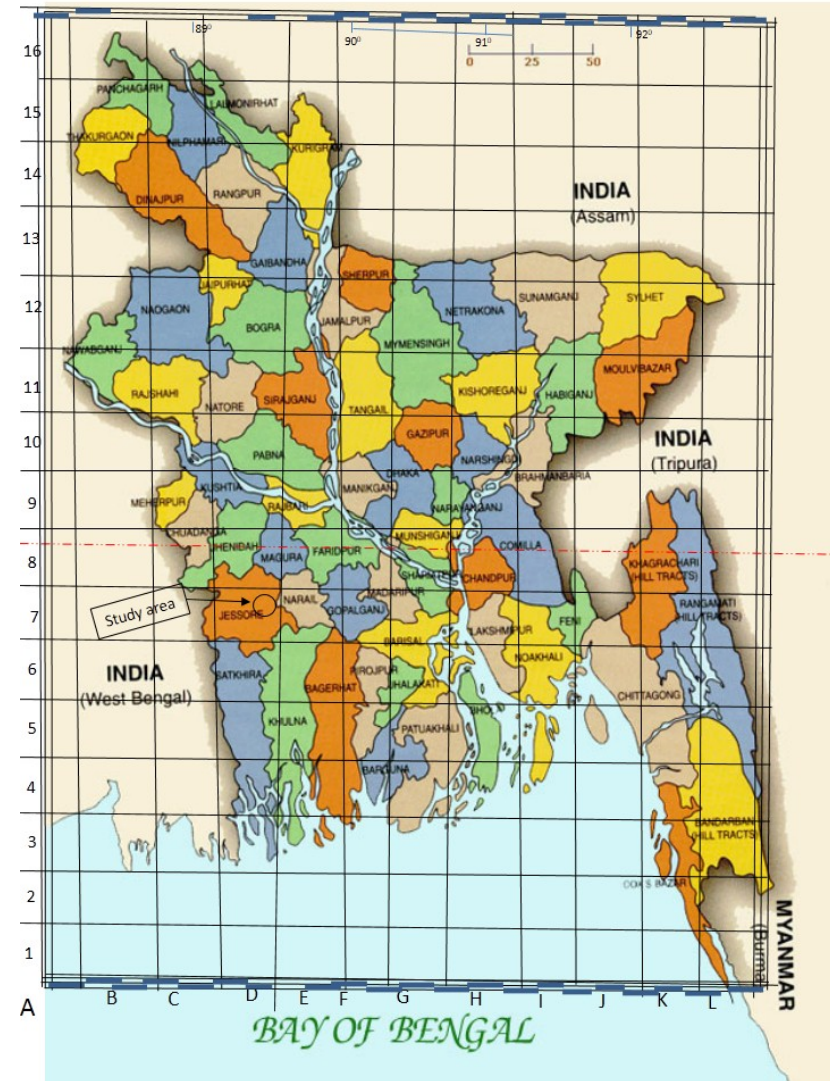

Figure 1. Map of Bangladesh showing location and site of the study of mite management

experimental unit. The treatment combinations were as follows:

$\mathrm{T}_{1}$ : Removing of flowers and foliar application of Omite@0.2\%

$\mathrm{T}_{2}$ : Removing of flowers and foliar application of Neem oil @0.3\%

$\mathrm{T}_{3}: \mathrm{T}_{1} \&$ soil incorporation of Neem cake @ $500 \mathrm{~g} /$ tree

T4: $\mathrm{T}_{1} \&$ soil incorporation of tricho-compost @ $2000 \mathrm{~g} /$ tree

$\mathrm{T}_{5}: \mathrm{T}_{2} \&$ soil incorporation of Neem cake @ $500 \mathrm{~g} /$ tree

$\mathrm{T}_{6}: \mathrm{T}_{2} \&$ incorporation of tricho-compost $2000 \mathrm{~g} /$ tree

Half of Neem cake and Tricho-compost along with other blanket fertilizer doses were 
applied in October 2011. Rest 50\% Neem cake as well as Tricho-compost along with other fertilizers were applied in April 2012. Dibbling method of application was used for applying fertilizers. In this method, fertilizers are placed in 4 to 6 inches deep holes, made around the root zones of palm at a distance of 1 meter from the base of the trunk. An iron made dibbler is used to make holes. The frame is pressed into the soil and then dropped in both side to make a hole by hand pressure. The holes are covered with soil after placing fertilizers. The soil around the palms is made moist by watering if needed and rendered weed free before fertilizing. Eight to ten wholes are made around the palm. Six treeclimbers, tow for each sub- location were hired for cleaning and spraying the palms in the study area. Before treating the palms, infected and distorted nuts as well as fruits up to six months old were removed from the palms. Initial numbers of both distorted and healthy nuts (if any) of each palm were recorded as baseline information while cleaning the crown palms for starting applying of treatments. The palms were then treated with six different treatments. Since, the mite of the infested palms re-attack the developing nuts, the palms out sides of the study unit of the area were therefore treated by abamecting (Islam et. al., 2008) to protect new born nuts of the experimental unit. First spray was done in October to November 2011 as soon as after cleaning the crown while the second spray was done in March to April, 2012 when the palms produced fruits and these fruits reached approximately 2-3 months old. Third and fourth sprays were done in two month intervals. Spray of miticide was done adjacent to the bunch area of crown as well as newly born nuts up to six months old. Palms outside the experimental unit were neither fertilized nor treated with Neem cake and Tricho-compost. The study was repeated in 2012-13 and 2013-14 for testing the consistency of the result.

\section{Data recording:}

Grading extent of surface damage of nut was done as follows.

i. Grade 0 - nuts with no mite damage ii. Grade 1 - nuts with 1-29\% surface area damage

iii. Grade 2- nuts with $30-59 \%$ surface area damage, $<20 \%$ reduction in size

iv. Grade 3 - nuts with $60-80 \%$ surface area damage, $20-30 \%$ reduction in size

v. Grade 4- nuts with over $80 \%$ surface area damage, over $30 \%$ reductions and greatly deformed

At the onset of the study, data on surface damage of nut, number of bunches and nuts per bunch of palm, kernel thickness and weight of nut of all marked palms were recorded as baseline information to compare the treatment effects. After applying treatments, when newly born nuts of palms reached four (4) to five (5) months old, data on surface damage was recorded again. Finally data on surface damage were recorded again when nut age reached around 10 months old.

\section{Data analysis and statistical tools applied:}

Average of three years data were used for statistical analysis. Statistical package MSTATC was used to determine ANOVA and Means were separated by DMRT. Means, average, standard deviation, co-efficient of variation (CV \%) were estimated by MS Excel to study the nature of data. Simple t-test was performed to compare means of each attributes before and after interventions.

\section{Results and discussion}

\section{Information on study area:}

The size of the study area was 696 hectares which represents an ecosystem unit and includes around 551 homesteads. Prevailing tropical monsoon climate of the location supports mixed vegetation with various annual and perennial tress including vegetable species. Coconut was a leading plantation species in the homesteads. Traditionally, coconut is grown in the homesteads with other fruits and orchard plantation is hardly found. Total number of coconut palms in the area was counted 4429 with an average of 8 palms per household (Table 1). The data revealed a decreasing trends of number 
of palms as compared to that of recent past. Islam et. al., (2010) conducted a survey on production and utilization of coconut in some leading coconut growing areas in Bangladesh during July 2001 to October 2002 and reported 9 to 37 palms per household with an average of 23 . Continuous yield loss due to mite attack in coconut and associated low income might cause farmers to cut down their palms and utilizing the land by shifting to cultivating other fruits or field crops (Islam et. al., 2017).

\section{Effect of treatments on surface damage of nuts:}

Data on surface damage of nut at early growth stage were recorded in April when nuts ages reached at around five months old while the data on mature stage were recorded in August when nut age reached around nine months old. No surface damage was noticed in nuts of early or mature stages of nuts. It was found that all the treatments was equally effective in controlling damage of nut surface (Table 2; Plates 7-8).

The hypothesis of the study was based on the life cycle of mite and nut growth of palms. Life cycle of coconut mite (CM) is 7-9 days and attacks coconuts immediate after fertilization of buttons (the female flower of coconut) for sucking saps from the growing nuts. Mite sucks nutrients from soft tissues under the perianth of stalk region of growing nuts. Mite cannot suck saps of tissues when nut reaches at age six months and above. So, removing and burning of nuts of palms up to 6 months old to capture and killed mite of the entire ecosystem under study. Virtually, the ecosystem would have mite free until appearing new fruits in the palms. It took around 50 days to come new fruits in the treated palms after the intervention. Spraying of growing nuts by miticide in two months intervals protected from re-attacks of mite. The hypothesis was supported by the findings of Ramarethinam and Loganathan (2000) and Islam et. al., (2008).

\section{Effects of treatments on Phonological events of inflorescence}

Days to opening of spathe, male phase, number of bunch and nuts per palms were not influence by the treatments. The edible portion of mature nuts, was found to improve by the treatments $\mathrm{T}_{3}$ and $\mathrm{T}_{5}$ which containing soil incorporated Neem cake (Table 2). The results were consistent in all three consecutive years. Neem cake, is a product of Neem seeds, containing trace of oil and other cellular components which acts as repellent of insect pests and give excellent effect on plant growth (Rao, 1991; Palma et. al; 2009). In addition insect repellent, after decomposition in rhizosphere and uptake, Neem cake enhance palms to biosynthesize necessary endogenous growth regulators and enzymes for growth and development and which might have encouraged palms to accumulate edible portion of nuts maximum (Palma et. al; 2009).

\section{Nut yield}

At the onset of the study, average nuts per palm were counted 12,17 and 18 in three locations. After intervention, yearly nut per palm in average were 119, 118, and 193 respectively (Table 3). Spraying new born nuts with mitides might have protected nuts from re-attack of mite and ensured higher yield of good quality nuts. It is to be noted that $50 \%$ of the nuts, harvested before intervention, were marketable and possessed price not more than half of price of normal nuts.

Morpho-anatomical study mite: Morphology of coconut mite was studied under stereomicroscope and documented. Mite colonies were not uniform in the infested nuts. Nuts of 2-6 month old were found to host colonies of mites beneath the perianth of stalk region (Plate 1). No mite was detected in unfertilized button (female flower) as well as in infected nuts of having age six months or above (Plates 2, 3). Button attains receptivity around one month after opening the spathe (Plate 10). Adults, nymphs and eggs were found in each colony (Plate 4). Triangular yellowish brown patches extending distally on the fruit surface from beneath the perianth of developing button indicated the typical symptoms of mite attack (Plate 5). Brown lesions were noticed around the stalk underneath the perianth of infected nuts. (Plate 1). Stalk region under the perianth of a healthy nut is bright white and fresh without any spot (Plate 9). 
Table 1: Land area, number of households and coconut palms in the study site

\begin{tabular}{|c|c|c|c|c|}
\hline Site & Area & Household & Palms & $\begin{array}{c}\text { Number of palms per } \\
\text { household }\end{array}$ \\
\hline & (ha) & (Nos.) & (Nos.) & (Nos.) \\
\hline Bolorampur & 63 & 75 & 393 & 5 \\
\hline Soyodmahmudpur & 190 & 91 & 1187 & 13 \\
\hline Parkul & 115 & 43 & 278 & 6 \\
\hline Budhopur & 81 & 52 & 479 & 9 \\
\hline Dorajhat & 137 & 166 & 706 & 4 \\
\hline Debinagor & 110 & 124 & 1386 & 11 \\
\hline Total $=$ & 696 & 551 & 4429 & - \\
\hline Average $=$ & 116 & 92 & 738 & 8 \\
\hline
\end{tabular}

(*Nation yield 21 nuts/palm; source: BBS, 2011)

Table 2. Effects of treatments on Phonology of inflorescence and fruit quality

\begin{tabular}{|c|c|c|c|c|c|c|c|c|c|}
\hline \multirow[t]{2}{*}{ Treatment } & \multirow{2}{*}{$\begin{array}{l}\text { Days to } \\
\text { opening of } \\
\text { spade }\end{array}$} & \multirow{2}{*}{$\begin{array}{c}\text { Days } \\
\text { to } \\
\text { male } \\
\text { phase }\end{array}$} & \multirow{2}{*}{$\begin{array}{c}\text { Bunch/ } \\
\text { palm }\end{array}$} & \multirow{2}{*}{$\begin{array}{l}\text { Nuts/ } \\
\text { bunch }\end{array}$} & \multirow{2}{*}{$\begin{array}{l}\text { Nuts/ } \\
\text { palm }\end{array}$} & \multicolumn{2}{|c|}{ Grading on pericarp spot } & \multirow{2}{*}{$\begin{array}{c}\text { Edible } \\
\text { portion } \\
\text { of } \\
\text { mature } \\
\text { nut } \\
\text { (kernel) }\end{array}$} & \multirow{2}{*}{$\begin{array}{c}\text { Dry } \\
\text { matter } \\
\text { of } \\
\text { kernel } \\
\text { at } \\
\text { maturity }\end{array}$} \\
\hline & & & & & & $\begin{array}{c}6 \text { month } \\
\text { after } \\
\text { intervention }\end{array}$ & $\begin{array}{l}10 \text { month } \\
\text { after } \\
\text { intervention }\end{array}$ & & \\
\hline & (Nos) & (Nos) & (Nos) & (Nos) & (Nos) & $(\%)$ & $(\%)$ & $(\%)$ & $(\%)$ \\
\hline $\mathrm{T}_{1}$ & 25.00 & 27.67 & 5.33 & 13 & 56.33 & 0 & 0 & $17.40 \mathrm{c}$ & 33.10 \\
\hline $\mathrm{T}_{2}$ & 22.00 & 27.67 & 5.33 & 13 & 58.67 & 0 & 0 & $15.83 \mathrm{c}$ & 31.30 \\
\hline $\mathrm{T}_{3}$ & 20.67 & 26.00 & 4.67 & 15 & 62.00 & 0 & 0 & $24.40 \mathrm{a}$ & 37.30 \\
\hline $\mathrm{T}_{4}$ & 25.67 & 25.67 & 5.00 & 14 & 63.67 & 0 & 0 & $16.90 \mathrm{c}$ & 36.80 \\
\hline $\mathrm{T}_{5}$ & 23.33 & 25.67 & 5.00 & 14 & 60.00 & 0 & 0 & $21.10 \mathrm{~b}$ & 38.10 \\
\hline $\mathrm{T}_{6}$ & 21.67 & 24.67 & 5.00 & 15 & 65.67 & 0 & 0 & $17.76 \mathrm{c}$ & 40.40 \\
\hline $\begin{array}{l}\text { Level of } \\
\text { significance }\end{array}$ & NS & NS & NS & NS & NS & & & 6.65 & 10.82 \\
\hline $\mathrm{CV} \%$ & 20.06 & 15.69 & 6.92 & 14.78 & 6.92 & & & $* *$ & NS \\
\hline
\end{tabular}

$\mathrm{T}_{1}$ : Removing of flowers and foliar application of Omite @ $0.2 \%$;

$\mathrm{T}_{2}$ : Removing of flowers and foliar application of Neem oil @ $0.3 \%$

$\mathrm{T}_{3}: \mathrm{T}_{1}$ \& soil incorporation of Neem cake @ $250 \mathrm{~g} /$ tree

$\mathrm{T}_{4}: \mathrm{T}_{1} \&$ soil incorporation of tricho-compost @ $1 \mathrm{~kg} /$ tree

$\mathrm{T}_{5}: \mathrm{T}_{2} \&$ soil incorporation of Neem cake @ 250g/tree

$\mathrm{T}_{6}: \mathrm{T}_{2} \&$ incorporation of tricho-compost $1 \mathrm{~kg} /$ tree 
Table 3. Yearly nut set after intervention in palms under experimental unit (average of three years)

\begin{tabular}{|c|c|c|c|c|c|c|}
\hline \multirow{2}{*}{$\begin{array}{l}\text { Sample } \\
\text { palm }\end{array}$} & \multicolumn{2}{|c|}{ Population 1} & \multicolumn{2}{|c|}{ Population 2} & \multicolumn{2}{|c|}{ Population 3} \\
\hline & $\begin{array}{c}\text { After } \\
\text { intervention }\end{array}$ & $\begin{array}{c}\text { Before } \\
\text { treatment }\end{array}$ & $\begin{array}{c}\text { After } \\
\text { intervention }\end{array}$ & $\begin{array}{c}\text { Before } \\
\text { treatment }\end{array}$ & $\begin{array}{c}\text { After } \\
\text { intervention }\end{array}$ & $\begin{array}{c}\text { Before } \\
\text { treatment }\end{array}$ \\
\hline 1 & 114 & 28 & 114 & 15 & 147 & 16 \\
\hline 2 & 115 & 7 & 103 & 18 & 159 & 18 \\
\hline 3 & 111 & 7 & 113 & 12 & 151 & 18 \\
\hline 4 & 123 & 12 & 133 & 20 & 150 & 26 \\
\hline 5 & 115 & 6 & 107 & 17 & 137 & 20 \\
\hline 6 & 118 & 8 & 103 & 16 & 151 & 15 \\
\hline 7 & 116 & 14 & 116 & 18 & 133 & 18 \\
\hline 8 & 211 & 16 & 119 & 18 & 132 & 24 \\
\hline 9 & 119 & 15 & 129 & 26 & 128 & 17 \\
\hline 10 & 119 & 11 & 134 & 20 & 133 & 16 \\
\hline 11 & 117 & 18 & 125 & 15 & 132 & 18 \\
\hline 12 & 105 & 17 & 117 & 18 & 125 & 16 \\
\hline 13 & 123 & 14 & 113 & 24 & 143 & 14 \\
\hline 14 & 113 & 10 & 120 & 17 & 129 & 18 \\
\hline 15 & 105 & 8 & 118 & 16 & 150 & 14 \\
\hline 16 & 129 & 11 & 132 & 18 & 150 & 14 \\
\hline 17 & 120 & 9 & 113 & 16 & 141 & 17 \\
\hline 18 & 111 & 8 & 123 & 14 & 132 & 19 \\
\hline 19 & 98 & 11 & 111 & 18 & 139 & 19 \\
\hline 20 & 98 & 10 & 113 & 14 & 136 & 18 \\
\hline 21 & 112 & 10 & 133 & 14 & 133 & 19 \\
\hline 22 & 114 & 9 & 117 & 17 & 97 & 18 \\
\hline 23 & 116 & 12 & 107 & 19 & 132 & 16 \\
\hline 24 & 111 & 13 & 119 & 19 & 119 & 14 \\
\hline 25 & 144 & 12 & 119 & 18 & 142 & 17 \\
\hline 26 & 124 & 15 & 95 & 19 & 447 & 16 \\
\hline 27 & 116 & 11 & 110 & 18 & 444 & 18 \\
\hline 28 & 129 & 17 & 125 & 16 & 450 & 18 \\
\hline 29 & 117 & 15 & 128 & 14 & 492 & 26 \\
\hline 30 & 106 & 7 & 116 & 17 & 475 & 20 \\
\hline Average & 119 & 12 & 118 & 17 & 193 & 18 \\
\hline $\begin{array}{l}\text { Standard } \\
\text { deviation }\end{array}$ & 19.64 & 4.50 & 9.66 & 2.86 & 125.59 & 3.06 \\
\hline $\mathrm{CV} \%$ & 16.51 & 37.39 & 8.22 & 16.46 & 65.09 & 17.07 \\
\hline t-stat & \multicolumn{2}{|c|}{55.74} & \multicolumn{2}{|c|}{50.98} & \multicolumn{2}{|c|}{124.14} \\
\hline $\begin{array}{l}\text { Level of } \\
\text { significance }\end{array}$ & \multicolumn{2}{|c|}{$* *$} & \multicolumn{2}{|c|}{$* *$} & \multicolumn{2}{|c|}{$* *$} \\
\hline
\end{tabular}


Table 4. Cost of investment per palm for controlling mite

\begin{tabular}{|c|c|c|c|}
\hline \multicolumn{4}{|l|}{ A. Cost of investment } \\
\hline Input used (Tk) & Unit price (Taka) & Quantity used & Cost (Taka) \\
\hline Neem oil cake $(\mathrm{Tk})$ & $: 50.00 / \mathrm{Kg}$ & $=1$ & 50.00 \\
\hline Omite (Tk) & : 140.00/100 ml & $=6 \mathrm{ml}$ & 9.00 \\
\hline Climbing (Tk) & : 30.00/climbing time & $=4$ & 120.00 \\
\hline Sprayer(Tk) & : 240.00/piece & $=1 / 100$ & 11.20 \\
\hline Labor for Neem cake(Tk) & : 300.00/day & $=1 / 300$ & 10.00 \\
\hline B. Income derived by technology (Tk) & & Total $=$ & 200.20 \\
\hline Number of nut obtained & :77 & & \\
\hline Market price/nut (Tk) & $: 20$ & & \\
\hline Income obtained (Tk) & $: 1540$ & & \\
\hline C. Profit (B-A) (Tk) & $: 1339.80$ & & \\
\hline \multicolumn{4}{|l|}{ D. Benefit Cost Ratio } \\
\hline Income before intervention (Tk) & $: 160$ & & \\
\hline Income due to intervention (Tk) & $: 1339.80$ & & \\
\hline Income augmented (Tk) & $: 1179.80$ & & \\
\hline BCR & 6.00 & & \\
\hline
\end{tabular}

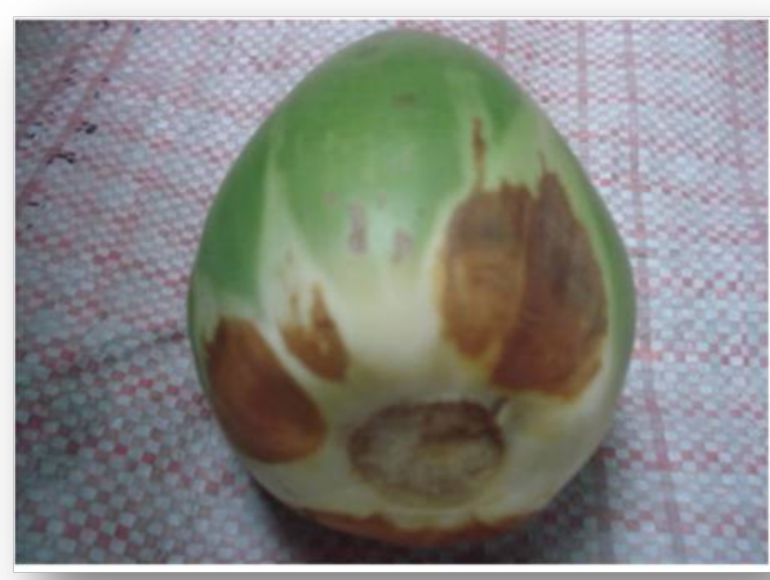

Plate 1. Mite infested tender nut of age about 3 month

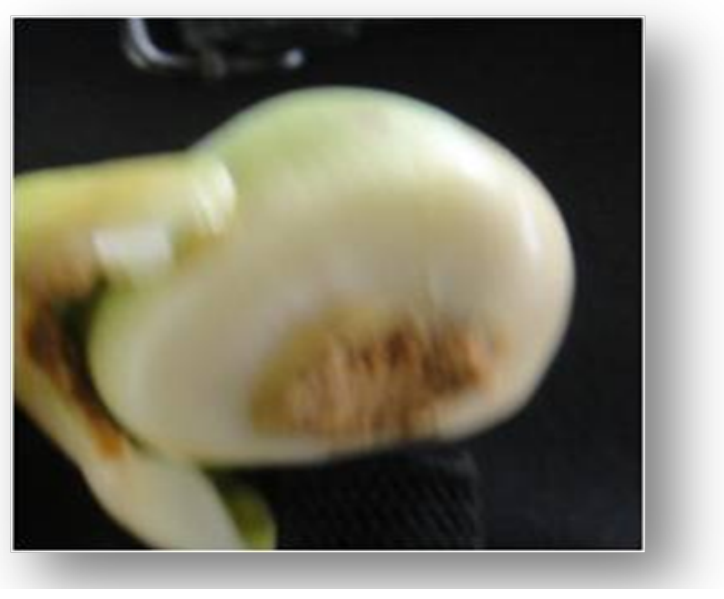

Plate 2. Unfertilized button nut without any sign of mite attack 


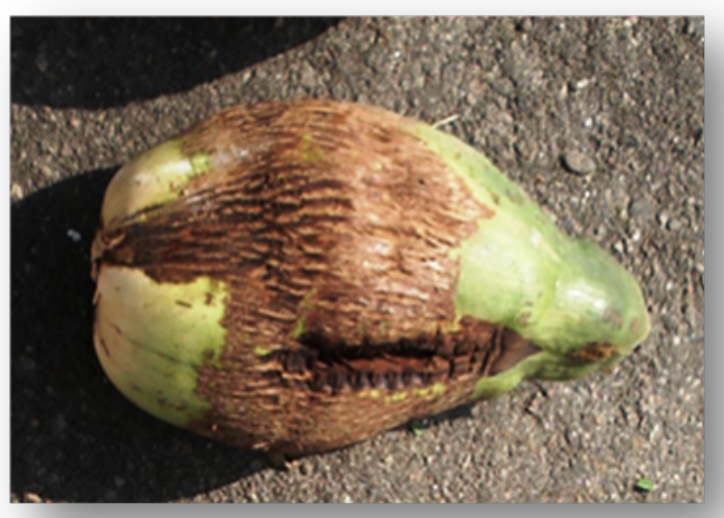

Plate 3. Mite infested nut of age about 7 months

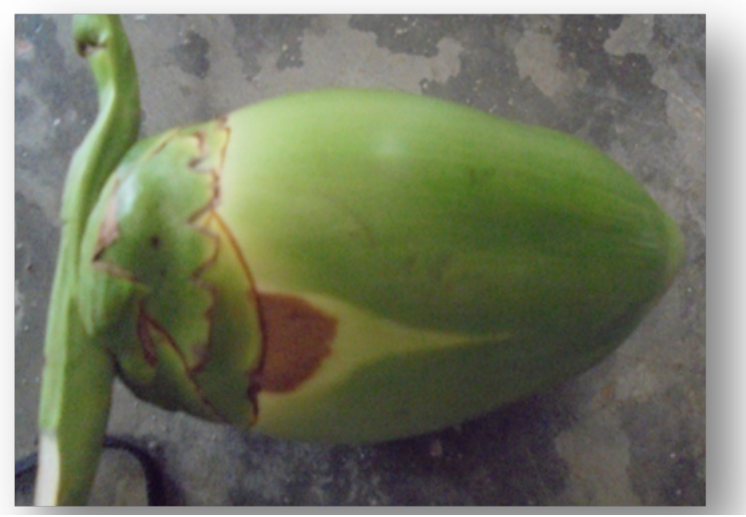

Plate 5. Triangular yellowish brown patches extending distally on the fruit surface

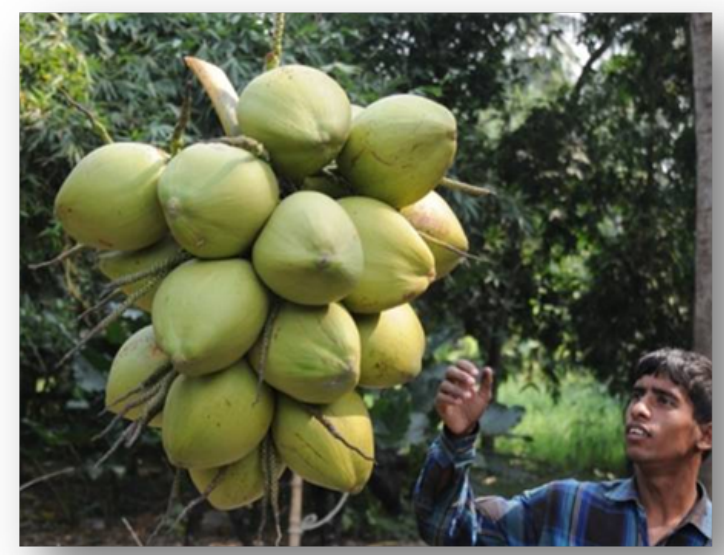

Plate 7. Harvesting damage free healthy coconut from a treated palm

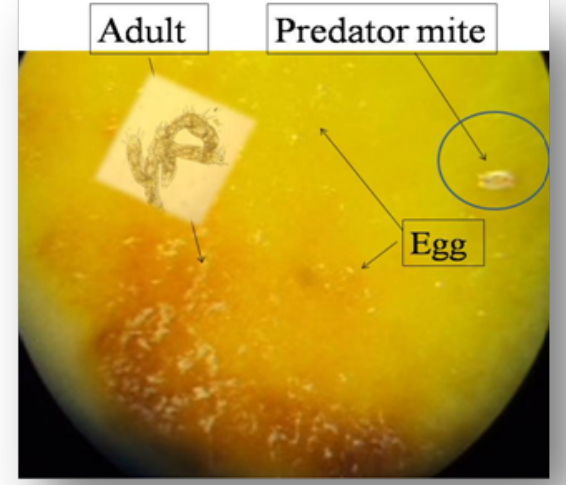

Plate 4. Adult, nymph, egg and predator mite in a colony

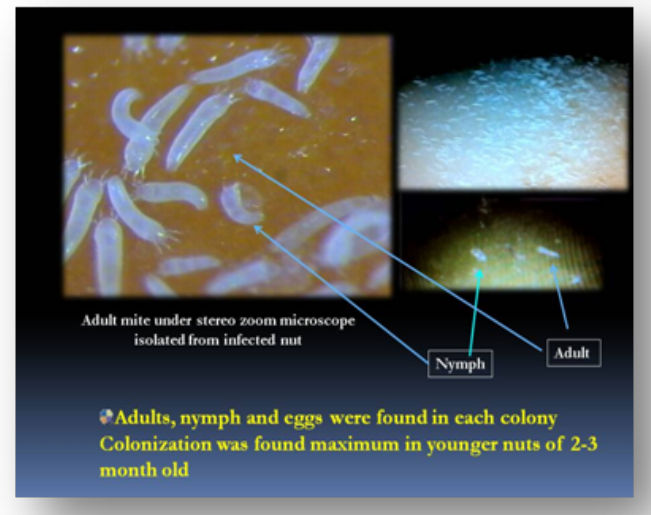

Plate 6. Coconut mite under stereo microscope

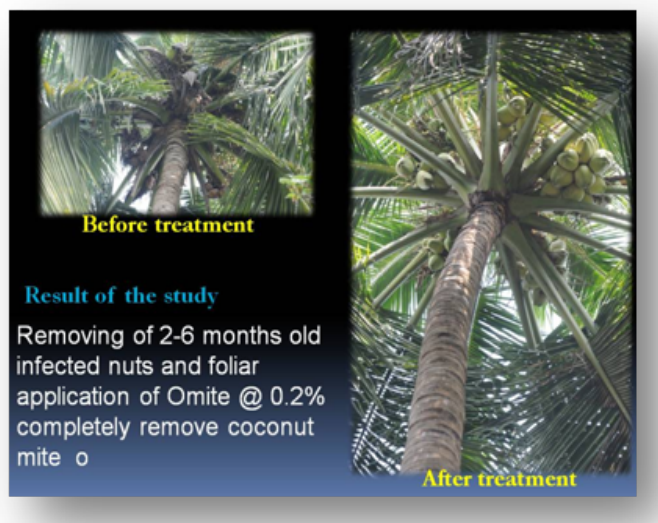

Plate 8. Mite infested palm (a) before treatment (b) after treatment 


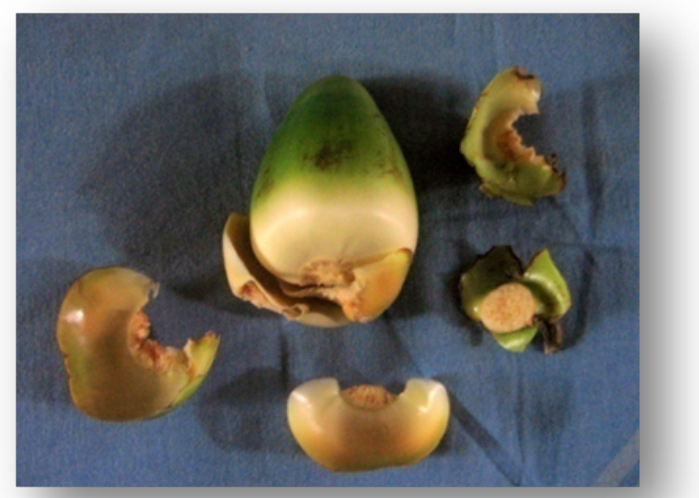

Plate 9. Female flower after fertilization

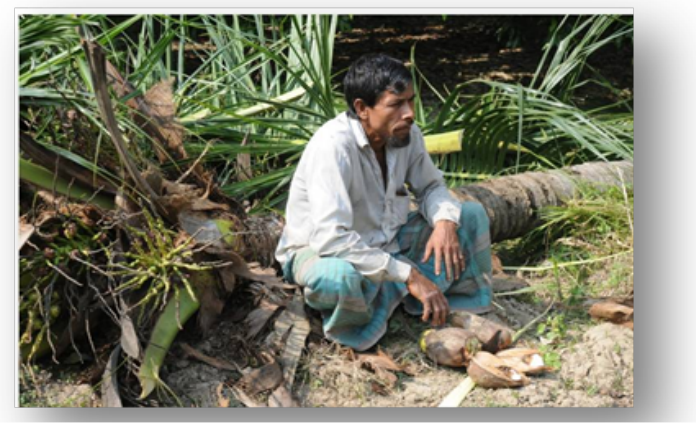

Plate 11. Coconut at the extinction due to mite

The mite was microscopic, slender, vermiform and whitish in color (Plate 6). Eggs were shiny white and globular in shape (Plate 4 \& 6). Cardona and Potes (1971), Julia and Mariau (1979) and Hall et al., (1980) similarly described and documented mite and infested nut.

\section{Impact of mite attack on harvesting of coconut}

Coconut mite was reported for the first time in Bangladesh in early 2004 and it was unidentified until 2008. Exact data on yield loss of coconut due to mite attack not available. According to Bangladesh Bureau of Statistics (BBS) Bangladesh produces yearly 100 million from an area of about 35 thousand hectares in Bangladesh. However, the current study estimates 8 palms per household with an average yield 16 nuts/palm/year (Table 3). Islam et al., (2010) conducted a survey in 23 major coconut growing areas of the country during July 2001October 2002 and reported 23 palms per

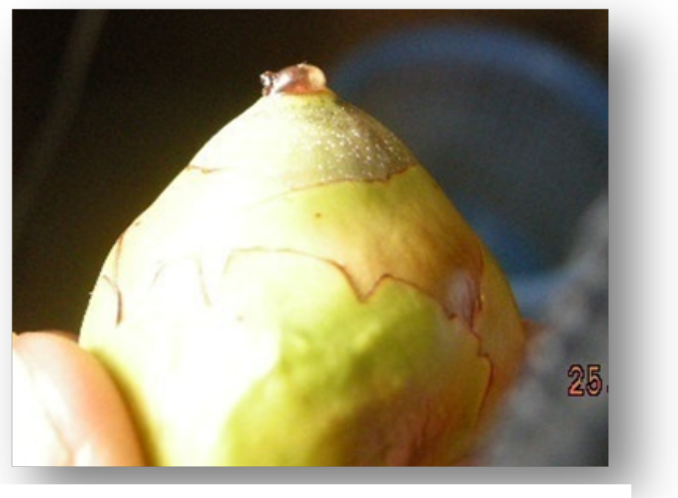

Plate 10. Receptive female flower

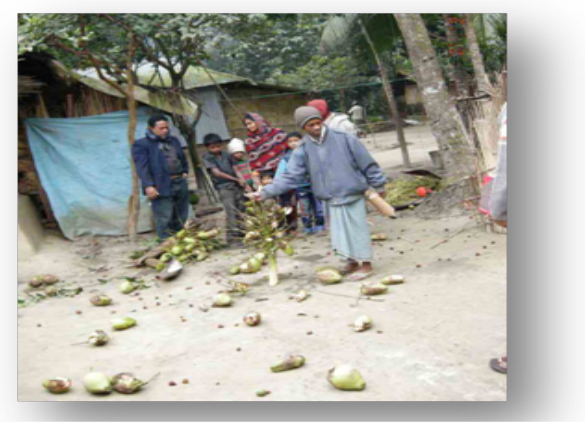
Plate 12. Infed nuts are cleaning before
spraying miticide

household with an average yield 75 nuts per palm per year. It is suspected that mite infestation is one of the major causes of such drop in coconut production in Bangladesh. Similar findings were also report by Islam et. al., (2016) and opined that due to continuous yield loss many farmers removed their palms and shifted to cultivate field crops. At the onset of the intervention, average number of marketable nuts per palm were 16 and their market price was half of the price of normal nut (Table 4).

\section{Economic analysis}

Cost of intervention per palm was Taka 200.20. Average nuts per palm were counted 50 to 216 with an average 77 , market price of which was estimated Taka 1540 (at the rate of Tk 20/nut). Benefit obtained due to the technology was Taka 1339.80. Before intervention, earning from a palm was estimated 160. Estimated benefit cost ratio (BCR) was 6 (Table 4). 


\section{Conclusion and recommendation}

The study have shown that infestation of newly developing fruits by coconut mite could be prevented by removal of infested fruits and treating palms with miticides in a large area. The investigation was the beginning of research on coconut mite in Bangladesh condition. For a sustainable recommendation continued investigations are required including chemicals and botanical extracts. The present technology retained the lost yield of coconut. As a result income and employment opportunities from coconut sector might promote more planting of coconut in the country. There is also a beneficiary effect of technology on environment by utilizing atmospheric carbon by coconut for its vegetative growth and fruit production round the year. The present technology may be recommended until a sustainable control measure and management practices against mite are developed.

\section{References}

BBS, 2011. Statistical Year Book of Bangladesh. Bangladesh Bureau of Statistical Division, Ministry of Planning and Evaluation, Government People's Republic of Bangladesh. Pp 558.

Brian J.B. Atwell., P. E. Kriedemann and C. G.N. Turnbull.1999. Plant in action (ed). Macmillan Education Australia Pty Ltd, Melbourne, Australia.

Cardona I. Z. and S.A. Potes. 1971. Coconut scab or excoriation (Cocos nucifera L.) in Columbia. A.guerreronis. Acta Agronomica 21: 133-139.

Eyzaguirre, P.B. and Pons Batugal (edited). 1999. Farmers Participatory Research on coconut Diversity: Workshops report on methods and field protocols. IPGRI-APO, P.O. Box 236, UPM Post Office, 43400 Serdang, Selangor Darul Ehsan, Malaysia. pp. 71-80.

Fernando, L.C.P., Moraes G.J. and I.R. Wickramananda. 2002. Proceedings of the International Workshop on Coconut Mite (Aceria guerreronis), Sri Lanka, 6-8
January, 2000. Coconut Research Institute, Sri Lanka. 117 pp.

Hall R.A., N.W. Hussey and D. Mariau. 1980. Results of a survey of biological control agents of the coconut mite Eriophyes guerreronis Keifer. Oléagineux 35: 395400.

Islam, M.N; M.S. Rahman; M.I. Islam; M.S. Nnahar; A.K. Azad and A.N.M. R. Karim. 2016. Analysis of farmers' participatory research on mite management in coconut in Bangladesh. JPC, 2016, 44(3): 72-75

Islam M.N., M.S. Rahman; S. Hossain, A.K. Azad and M.S. Islam. 2010. Socioeconomic status of farming communities based on utilization of coconut (Cocos nucfera L) in Bangladesh. Bangldesh J. Agri. 35(2): 145-153

Islam M.N.,M.F. Hossain, M.A. Hossain, M.I. Islam, M. Rafiuddin, M.F. Ahmad and R. Ali, 2008. Preliminary study on Integrated Management Practices for the control of young nuts and immature bud drop of coconut in Bangladesh. The Philippine Journal of Coconut Studies. 33(2): 64-69.

Julia J.F and D. Mariau. 1979. Nouvelles recherches en Côte d'Ivoire sur Eriophyes guerreronis Keifer, acarien ravageur des noix du cocotier. Oléagineux 34: 181-189.

Keifer, H.H. 1965. Eriophyid Studies 10-14, California Department of Agriculture Bureau of Entomology, p. 20.

Palma J.M., F.J. Corpas and L.A. del Rio. 2009. Proteome of plant peroxisomes: new perspectives on the role of these organelles in cell biology. Proteomics. 9 (9): 230112.

Rao, 1991. Tex Book of Horticulture. Macmillan India Ltd Ltd. 2/10 Ansari Road Darygonj, New Delhi 110002. India Pp. 295.

Ramarethinam, S. and S. Loganathan. 2000. Biology of Aceria guerreronis Keifer (Acari: Eriophyoidea; Eriophyidae) - A perianth mite infesting coconut groves in India. Pestology, 24 (6): 6-9. 
Cord 2018, 34 (2) 